\title{
最先端外科：外科医の求める麻醉管理と答える麻醉科医 泌尿器科ロボット支援腹腔鏡下手術の麻酔管理
}

板橋俊雄*

[要旨]ロボット支援手術は術後の回復が早く低侵襲であるが, 術中は特殊な麻酔管理が必要となる. また，外科医が手術に集中し，患者の安全を高めるために，麻酔管理が貢献できる点もある．特殊 な体位による合併症や，機械類の患者への接触を避けるだけでなく，良好な術野の確保にも麻醉管 理が寄与する．昨今，前立腺摘除術でのロボット支援下手術が急速に国内で広まった．ロボット支 援下手術は, 泌尿器科領域の腎部分切除や膀胱全摘, 他に産婦人科や消化器外科などさまざまな手 術でも始まっている．前立腺摘除術での経験をもとに，新たな広がりを見せるロボット支援下手術 の麻酔管理について, 検討し普及していかなければならない. キーワード : 泌尿器科手術, ロボット支援下手術, 麻酔管理

\section{I＼cjkstart米国と日本におけるRARPの歩み}

根治的前立腺摘除術は，米国において1996年に はすべて開腹手術で行われていた。2000年以降に ロボット支援手術が開始されたが, 腹腔鏡手術は口 ボット支援手術に先んじて始まったものの, すぐに 減少した。その後, ロボット支援手術は2006年に 半数近くに増加し， 2007 年には開腹手術を逆転し た。そして，2009年には根治的前立腺摘除術の 85 \%以上がロボット支援下で行わ机るようになり, 限 局性前立腺癌に対する標準術式として定着した ${ }^{1)}$. 一方，日本では2009年11月に da Vinci surgical systemが薬事承認され，2012年 4 月にロボット支援根 治的前立腺摘除術 (robot-assisted radical prostatectomy：RARP) が保険収載されたが，この時点で米 国に約 10年遅水ていた。

\section{RARPの合併症}

当院におけるda Vinci手術は，2005年に心臟手 術, 2006 年泌尿器科, 2009 年婦人科, 消化器外科, 呼吸器外科, 耳鼻科で始まった。各科のロボット手 術に抢いて, 出血以外に大きなトラブルは発生して おらず，特に前立腺手術においては開腹術に比へてて 出血量が少ないなどの利点が多いため, 手術件数は 増加してきた。2006年 8 月から 2016年 9 月に当院 で施行されたRARP 1,804例の外科的合併症は，膀 胱損傷が 6 例，小腸損傷が 3 例なぞ，計 16 例で発生 率は $0.9 \%$ であっ(表 1)。一方，海外でのメタアナ リシスに打いて，2002年から 2010年のRARP症例 62,389 例での合併症発生率は, 血管損傷 $0.03 \sim 0.1$ $\%$ ，神経損傷 $0.1 \sim 0.7 \%$ ，尿管損傷 $0.002 \sim 0.2 \%$ で あり, 恥骨後式前立腺摘除術 (retropubic radical prostatectomy : RRP) や腹腔鏡下前立腺摘除術 (laparo-

*東京医科大学麻酔科学分野

著者連絡先 板橋俊雄

者 160-0023 東京都新宿区西新宿 6-7-1 東京医科大学麻酔科学分野 
表 12006 年 8 月〜2016年9月に当院で施行したRARP 1,804 例における外科的合併症

\begin{tabular}{lcc}
\hline 術中合併症 & $\mathrm{n}$ & 発生率(\%) \\
\hline 小腸損傷 & 3 & 0.17 \\
外腸骨静脈損傷 & 2 & 0.1 \\
外腸骨動脈損傷 & 1 & 0.05 \\
膀胱損傷 & 6 & 0.3 \\
直腸損傷 & 1 & 0.05 \\
閉鎖神経損傷 & 2 & 0.1 \\
尿管損傷 & 1 & 0.05 \\
\hline 計 & 16 & 0.9 \\
\hline
\end{tabular}

scopic radical prostatectomy : LRP) と比較し, RARP の合併症率は有意に低い結果であった ${ }^{2)}$ 。このよう に，RARPは外科的合併症においては安全な手術と 言うことができる。

膀胱損傷，直腸損傷，尿管損傷，閉鎖神経損傷な どがRARPの主な外科的合併症であるが，非外科 的合併症としては，体位による神経や筋肉の損傷， ロボットアームによる圧排, カメラによる顔面や眼 球の損傷，喉頭浮腫，皮下気腫，空気塞栓などがあ る。これらの非外科的合併症を起こさないようにす ることは麻酔科医の責務として当然であるが，加え て外科的合併症を起こす要因となるものを少しでも 取り除くことも大切な役割である.

\section{RARP の麻酔管理の特徵}

RARPの麻酔法としては, 吸入麻酔薬のセボフル ランやデスフルラン, 静脈麻酔薬のプロポフォール のどれも可能である。当院では硬膜外麻酔を行わな いので, 術中鎮痛はレミフェンタニルで行い, 術後 鎮痛にフェンタニルやNSAIDs, アセトアミノフェ ンなどを用いる．筋弛緩はロボット操作中に十分に 得るためにロクロニウムを持続投与し, ロボット操 作後の閉腹時間が短いので，スガマデクスによる拮 抗が有効である.筋弛緩モニターの使用が好ましい.

麻酔管理にかかわるRARPに特徵的な問題点に ついては, 高度頭低位(図1)や二酸化炭素による気
腹に伴う影響が大きい. 中枢神経系では，頭低位に より頭蓋内压は上昇し，脳灌流は低下する。そのた め，脳血管障害の既往がある患者で注意が必要であ り，未破裂脳動脈瘤や頭蓋内圧立進患者は原則禁忌 と考えられる。また，眼圧は頭低位と気腹で有意に 上昇するとされ3), 永続的視神経障害が起きたとい う報告もある ${ }^{4)}$.

呼吸管理では，頭低位と気腹により，胸腔や気道 内圧の上昇をきたす。また，頭低位での横隔膜挙上 と気腹時に使用される二酸化炭素により, 高二酸化 炭素血症となりやすい。そして，血中二酸化炭素濃 度の上昇は, 頭蓋内圧や眼圧の上昇の原因となる。 換気様式については, 従量式換気に比べ従圧式換気 では気道内压の上昇と肺コンプライアンスの低下を 抑制するものの，その他の呼吸因子や循環動態には 有意差はない ${ }^{5)}$ 。従量式では気道内圧上昇からの圧 外傷, 従圧式では換気量低下からの高二酸化炭素血 症に注意が必要である。

循環においては，頭低位により血圧は上昇し，心 拍出量は増加するが, 気腹に伴う心拍出量低下もあ り，麻酔管理上の悪影響は少ないと考えられる。し かし, 弁膜疾患が一時的に増悪したという報告があ り，心臓弁膜症患者は心エコーなど十分な評価が必 要である ${ }^{6)}$. また，肺血管抵抗は増加するため，肺 高血圧のある患者でも注意を要する。気腹と頭低位 が呼吸と循環に及ぼす影響を表2に示す。

体位固定やロボットとの接触による合併症とし て, 肩部への圧迫に起因する腕神経叢麻痺がある ${ }^{7}$. また，臍直上ポートのカメラ動作による前胸部や下 顎部への接触の可能性が考えられるため, 前胸部は クッション，下顎部は離被架で外傷を予防する。下 肢とロボットの支柱との接触にも注意が必要で，3rd アームと大腿部, 下腿部の接触に起因するコンパー トメント症候群の報告がある ${ }^{8)}$. 頭低位での砕石位 では，下腿にレビテーターを使用するが，血流障害 によるコンパートメント症候群や腓骨神経などの神 経障害が報告されており，レビテーターの固定に注 


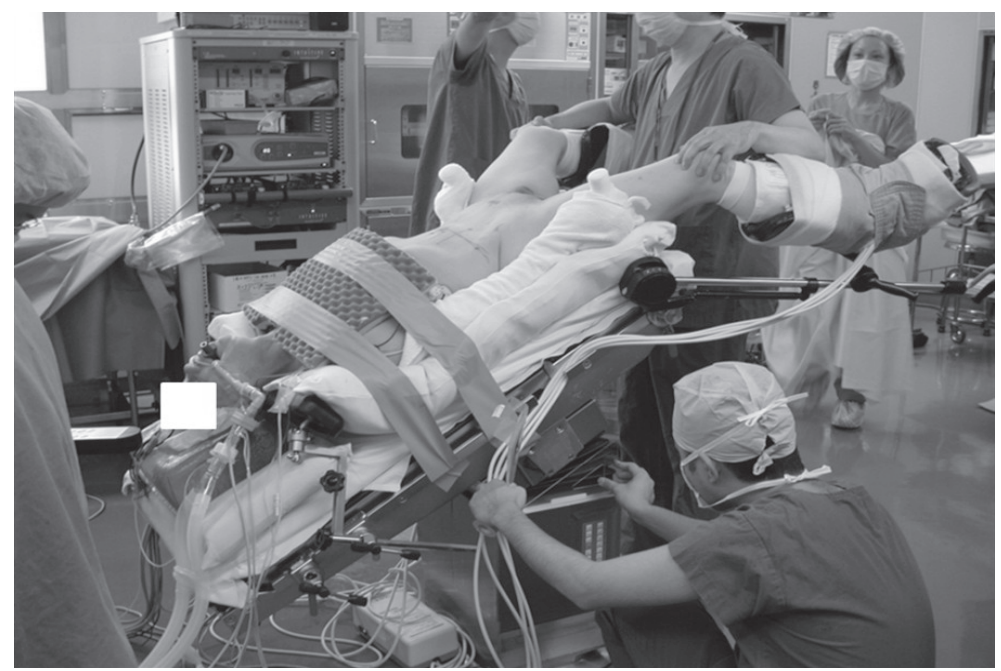

図1 RARP の体位

頭低位 $30^{\circ}$ の砕石位.

表2 気腹と頭低位による呼吸，循環における变化

\begin{tabular}{l|l}
\hline 気腹に伴う変化 & 頭低位に伴う変化 \\
\hline 胸郭コンプライアンス低下 & 肺コンプライアンス低下 \\
動脈血二酸化炭素分圧上昇 & 機能的残気量低下 \\
心拍出量低下 & 心拍出量増加 \\
血圧上昇 & 中心静脈圧上昇 \\
血管抵抗増加 & 末梢血管抵抗減少 \\
肺血管抵抗増加 & \\
\hline
\end{tabular}

意する。また，肩部，仙骨部，踵部など，さまざま な部位で裖瘡の可能性がある。深部静脈血栓症予防 には弾性ストッキングとフットポンプを使用する。 術後は浮腫に注意が必要で, 頭䅡部浮腫が生じて, 抜管後の気道狭窄が起きることもある7). 皮下気腫 も起きやすく, 䅡部に高度に認めるときには気道狭 窄に注意する。喉頭ファイバーによる観察やカフリ ークテストなどで気道を評価し，チューブエクスチ エンジャーを用いた抜管を考慮する。気道狭窄が強 く疑われるときは挿管のまま, 浮腫や皮下気腫が改 善するのを待つ。また，手術室退室までに上下肢の 神経障害や，全身の裖瘡などの評価も行う。

\section{IV 外科医の求める麻酔管理}

外科医が麻酔科医に求める麻酔管理は，患者に合 併症を起こさないことであり，ロボット支援手術も 例外ではないが，RARPにおける特徵的な点を以下 に示す(表3)。術前は患者リスクの把握が非常に重 要であるが，頭低位の影響から，脳と眼の合併症に 特に注意する。術中は外科的合併症を減らすため, 良好な術野を提供することが麻酔管理上の課題とな る。具体的には十分な筋弛緩と輸液制限である。尿 量が多いと，尿道再建時に吻合が困難となるため, 輸液負荷せずに尿量増加を避けるべきである ${ }^{9)}$ ，過 剰輸液は術後の浮腫の増悪にもつながる.

筋弛緩については, 前立腺切除と腎切除術の腹腔 


\begin{tabular}{|c|c|}
\hline 術前 & 合併症の把握 (特に脳, 眼, 弁膜症) \\
\hline 麻酔中 & $\begin{array}{l}\text { 非外科的合併症対策(体位，機械と患者の接触） } \\
\text { 外科的合併症対策 (十分な筇弛緩，輸液制限）－良好な術野 } \\
\text { 緊急時の対処 (事前のシミュレレーション) }\end{array}$ \\
\hline 術後 & $\begin{array}{l}\text { 気道浮腫 } \\
\text { 皮下気腫 } \\
\text { 神経障害や裖㿊の確認 }\end{array}$ \\
\hline
\end{tabular}

鏡手術において, train-of-four(TOF) カウントで1 〜2の浅い筋弛緩と比べて, テタヌス後単回刺激反 応数 (PTC)で1〜2の深い筋弛緩では優位に術野の 質が良い ${ }^{10)}$ 。また, RARPにおいて, 浅い筋弛緩と 比べて深い筋弛緩では, 術野の質が良く, 腹腔内圧 (IAP ; intra-abdominal pressure) も低く, 眼圧(IOP ; intraocular pressure) も低かった ${ }^{11}$. 十分な筋弛緩 は術野の質を上げるとともに，腹腔内圧や眼圧を上 げず，気腹圧を下げることにつながり ${ }^{12)}$ ，患者の安 全や合併症の軽減に寄与する。術後の抜管時には, 頭䅡部の浮腫や重度の皮下気腫に伴う気道トラブル に留意が必要である。

ロボット操作中に患者急変が起きたときには，ロ ボットアームを患者から外し, ロボット本体を患者 から離した上でベッドを平坦に戻し，胸骨圧迫やラ イン確保などの処置を行わなければならない。その ために，日ごろからその手順について訓練を行い， 緊急時に備えるべきである。外科医, 麻酔科医, 看 護師，臨床工学技士など，ロボット手術にかかわる すべての人の連携が大切である。

\section{RARP以外のロボット支援泌尿器科手術}

ロボット支援手術はRARPが多くの施設で行わ れるようになってきたが, 産婦人科や消化器外科手 術などの手術にも拡大している。泌尿器科では, 膀 胱全摘術や腎臓部分切除術がロボット支援下で始ま つている。ロボット支援膀胱全摘術 (robot-assisted radical cystectomy : RARC)では体位はRARP と同
じく頭低位の砕石位であるため，麻酔管理の注意点 はRARP と同様であるが，尿路変更があるため手術 時間が長くなり，どこまでロボット操作で行うかな ぞ, 術式について確認が必要である。ロボット支援 腹腔鏡下腎切除術 (robot-assisted laparoscopic partial nephrectomy：RALPN) は二酸化炭素による気 腹はするが，側臥位の軽いジャックナイフ位(図2) であるため，RARPのような高度頭低位による影響 はなく, 呼吸や循環など麻酔管理上の問題点は少な い. 下側の無気肺や皮下気腫，血管損傷が主な問題 となる。緊急時には体位を側臥位から仰臥位に戻す 必要があり, RARP 以上に困難が予想されるため, 十分な準備が必要となる。また，アプローチが，腫 瘍の位置により経腹膜アプローチと後腹膜アプロー チがあり，ペイシェントカートがそれぞれ患者の背 側と, 腹側に位置するため, 術前の配置に注意する。

\section{まとめ}

ロボット支援下手術は外科的な面からは, 術後痛 や出血が少なく，回復も早いことから低侵襲である が，麻酔管理上は特殊な管理が必要で，侵襲やリス クは少なくない。 下腹部手術では，高度頭低位や二 酸化炭素による気腹で呼吸・循環・脳神経系に影響 を与える。また，ロボット操作中は患者周囲に機械 類が配置されるため, 患者へのアクセスが困難とな る。緊急事態発生時にはロボットを患者から離し, 頭低位を解除せね齐ならず，その手順を迅速に遂行 できるよう事前のトレーニングが欠かせない。外科 


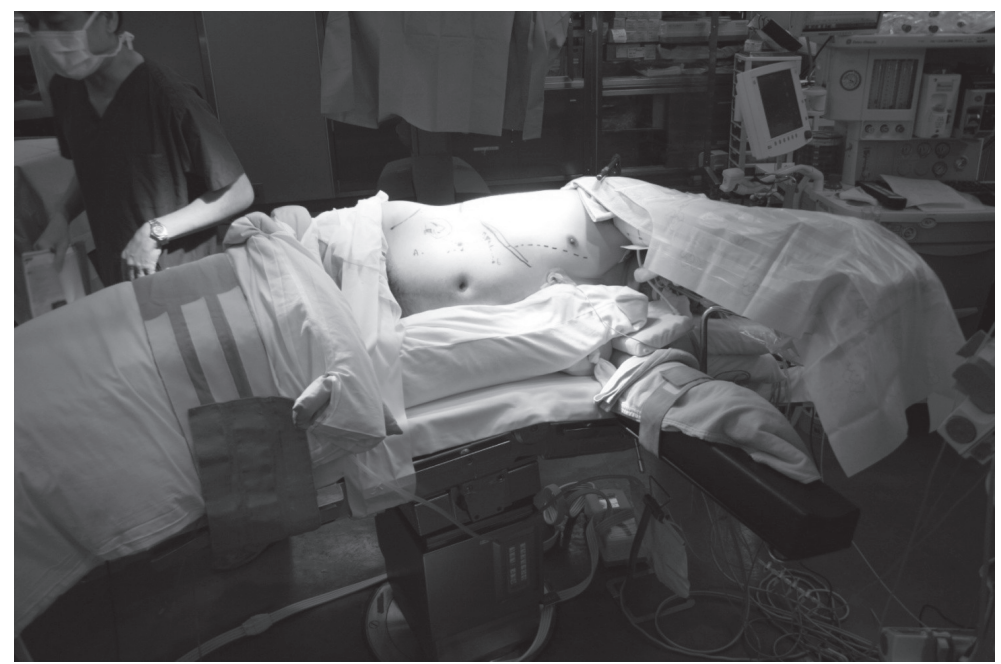

図2 RALPNの体位

右腎部分切除のため, 左側臥位で軽度のジャックナイフ位.

医が手術に集中し, 患者の安全を維持するために麻 酔管理で注意する点があるが，特殊な体位による神 経障害や裖瘡, ロボットアームなど機械類の患者へ の接触を避けるだけでなく, 良好な視野の確保にも 麻酔管理がかかわる。

患者の利点から，ロボット手術はさらに拡大して いくものと思われる。今までのRARPでの経験を 活かし, 今後広まっていくさまざまなロボット支援 手術への対策を進め, 多くの麻酔科医が情報共有し, ロボット手術における患者の安全性を高めていかな ければならない.

\section{参考文献}

1) Zorn $\mathrm{KC}$, Gautam G, Shalhav AL, et al. : Training, credentialing, proctoring and medicolegal risks of robotic urological surgery : recommendations of the society of urologic robotic surgeons. J Urol 182 : 1126-1132, 2009

2) Tewari A, Sooriakumaran P, Bloch DA, et al. : Positive surgical margin and perioperative complication rates of primary surgical treatments for prostate cancer : a systematic review and meta-analysis comparing retropubic, laparoscopic, and robotic prostatectomy. Eur Urol 62 : 1-15, 2012

3) Awad H, Santilli S, Ohr M, et al. : The effects of steep
Trendelenburg positioning on intraocular pressure during robotic radical prostatectomy. Anesth Analg 109: 473-478, 2009

4) Weber ED, Colyer MH, Lesser RL, et al. : Posterior ischemic optic neuropathy after minimally invasive prostatectomy. J Neuroophthalmol $27: 285-287,2007$

5) Choi EM, Na S, Choi SH, et al. : Comparison of volume-controlled and pressure-controlled ventilation in steep Trendelenburg position for robot-assisted laparoscopic radical prostatectomy. J Clin Anesth 23 : 183188, 2011

6) Haas $\mathrm{S}$, Haese A, Goetz AE, et al. : Haemodynamics and cardiac function during robotic-assisted laparoscopic prostatectomy in steep Trendelenburg position. Int J Med Robot $7:$ 408-413, 2011

7) Phong SV, Koh LK : Anaesthesia for robotic-assisted radical prostatectomy : considerations for laparoscopy in the Trenderenburg position. Anaesth Intensive Care $35: 281-285,2007$

8) Rosevear HM, Lightfoot AJ, Zahs M, et al. : Lessons learned from a case of calf compartment syndrome after robot-assisted laparoscopic prostatectomy. J Endourol $24: 1597-1601,2010$

9) D’Alonzo RC, Gan TJ, Moul JW, et al. : A retrospective comparison of anesthetic management of robotassisted laparoscopic radical prostatectomy versus radical retropubic prostatectomy. J Clin Anesth 21: 322-328, 2009

10) Martini CH, Boon M, Bevers RF, et al. : Evaluation of 
surgical conditions during laparoscopic surgery in patients with moderate vs deep neuromuscular block. Br J Anaesth 112 : 498-505, 2014

11) Yoo YC, Kim NY, Shin S, et al. : The intraocular pressure under deep versus moderate neuromuscular blockade during low-pressure robot assisted laparoscopic radical prostatectomy in a randomized trial.
PLoS One 10 : e0135412, 2015

12) Bruintjes $\mathrm{MH}$, van Helden EV, Braat AE, et al. : Deep neuromuscular block to optimize surgical space conditions during laparoscopic surgery : a systematic review and meta-analysis. Br J Anaesth $118: 834-842$, 2017

\title{
Anesthetic Management under Robot-assisted Laparoscopic Surgery in the Field of Urology
}

\author{
Toshio ITABASHI \\ Department of Anesthesiology, Tokyo Medical University
}

Robot-assisted surgery is less invasive than conventional surgery and is followed by earlier postoperative recovery, but it requires specific anesthetic management during operation. Good anesthetic management contributes to safer surgery and better therapeutic outcomes by enabling surgeons to more closely concentrate on their job during surgery. It also makes it possible to prevent complications due to unusual posture and contacts of the robot with part of the body and helps secure a good operating field.

Recently, robot-assisted surgery has rapidly gained popularity in laparoscopic prostatectomy and is also spreading into other fields of urology such as partial nephrectomy and total cystectomy. It is also being increasingly conducted in other fields such as gynecology and gastroenterology. Anesthesiologists should further improve anesthetic management under robot-assisted surgery to increase its popularity based on experience acquired in prostatectomy.

Key Words : Urological surgery, Robot-assisted surgery, Anesthetic management

The Journal of Japan Society for Clinical Anesthesia Vol.39 No.1, 2019 